\title{
Produção de conhecimento sobre hidrelétricas na área de ciências humanas no Brasil
}

\section{Production of knowledge about hydroelectric dams in the social sciences in Brazil}

Edna Castro - Doutora em Sociologia pela École des Hautes Études en Sciences Sociales, Paris (França), professora da Universidade Federal do Pará, atuando no Núcleo de Altos Estudos Amazônicos (NAEA/UFPA) e no Programa de Pós-Graduação em Sociologia e Antropologia do Instituto de Filosofia e Ciências Humanas (IFCH/UFPA), e pesquisadora de produtividade do CNPq. E-mail: edna.mrcastro@gmail.com

\section{Resumo}

Este artigo discute a produção do conhecimento sobre hidrelétricas, no Brasil, na área das Ciências Sociais, visando explicitar como a pesquisa tratou esse tema e as situações associados à emergência de conflitos sociais e ambientais em contexto de licenciamento e de construção de grandes obras hidrelétricas. Esses processos têm sido marcados por interesses que levam a diferentes constrangimentos, confrontos e violência. A política energética do Brasil ao definir as diretrizes para construção de hidrelétricas, atende a novas demandas de expansão de setores econômicos entre eles o mineral e o agronegócio que têm ocupado papel determinante no processo de reprimarização da economia nacional ao fortalecer o modelo de crescimento neoextrativista com base na exportação de commodities. Atualmente, as políticas governamentais de infra-estrutura são centrais nas diretrizes do planejamento nacional.

\section{Palavras-chave}

Produção de conhecimento. Hidrelétricas. Ciências Sociais. Conflitos Socioambientais. Brasil.

\begin{abstract}
The author discusses production of knowledge on hydroelectric power plants in Brazil, from a Social Science angle, aiming to explain how research has dealt with this subject and the situation associated to the emergency of environmental and social conflicts in the context of licensing that are marked by constraints, conflicts and violence. When defining the guidelines for construction of hydroelectric dams, the Brazilian energy policy meets the new demands of expansion of economic sectors, among them mining and agribusiness, which have played an important role in the process of reprimarization of the national economy by strengthening the growth model based on exports. These questions are treated in relation to government policies of the electric sector.
\end{abstract}

\section{Keywords}

Production of knowledge. Hydroelectric. Social Sciences. Socioenvironmental Conflicts. Brazil. 


\section{INTRODUÇÃO ${ }^{1}$}

Desde meados do século XX observa-se, no mundo, uma tendência para construir grandes obras que se sobressaem e se impõem na paisagem. As grandes hidrelétricas resultam de decisões políticas estratégicas do planejamento estatal e de um conjunto de ações organizadas por agentes econômicos com objetivos de apropriação e transformação de recursos naturais em valor e mercadoria, a energia elétrica. Instalam-se em territórios muitas vezes expropriados de seus antigos moradores e apropriados pela indústria intensiva de eletricidade para uso privado, até mesmo exclusivo, visando a produção de valor. Efetivamente, a modernidade, com suas tensões no conhecimento e no imaginário, altera com rapidez e tecnologia mesmo as dimensões mais profundas da existência humana e da relação desta com a natureza.

Ao definir os planos e as diretrizes para construção de hidrelétricas, a política energética do Brasil objetivava atender as novas demandas de expansão de setores econômicos e do aumento do consumo, considerando o crescimento demográfico, a urbanização e a dinâmica do desenvolvimento. Os planos e programas nacionais, a partir dos anos 1950, privilegiaram a produção de energia a partir dos rios, razão do Brasil ter se tornado um dos principais construtores de usinas hidrelétricas no mundo, e ter, atualmente, quase $70 \%$ de sua matriz energética proveniente de usinas hidrelétricas (MME, 2017). O ideário político do modelo nacional-desenvolvimentista que empolgara a década de 1950, orientou as estratégias econômicas voltadas à industrialização do país, criando novo padrão na demanda de energia. É desse início de década a decisão de construir a Usina Hidrelétrica de Furnas. Desde o governo de Getúlio Vargas há incentivos para construção de hidrelétricas, ampliando-se no governo Kubitschek e, mais ainda, naqueles da ditadura militar quando seriam construídas, entre outras, as mega hidrelétricas de Itaipu, no Paraná, Tucuruí, no Pará, Balbina no Amazonas, e Sobradinho, na Bahia.

As grandes obras hidrelétricas são resultado de um complexo processo de negociação entre grupos e corporações reconhecidos no cenário econômico e político, nacional e internacional, pois a sua construção sempre está associada a outras dinâmicas econômicas (CASTRO et al., 2014). Na agenda sobre o futuro do planeta a questão da energia é central, porém, é importante pensar nos usos a serem dados a ela e aos recursos naturais explorados para sua produção.

\footnotetext{
Este artigo foi realizado no âmbito do projeto de pesquisa Estado e Sociedade: uma análise de ciência, poder e campo do desenvolvimento, Bolsa de Produtividade do CNPq.
} 
O debate que ocorreu no Brasil, e no mundo, nos anos 1980, influenciou a produção de novos conhecimentos. Pesquisadores, lideranças intelectuais de movimentos sociais, e profissionais de várias formações, se interessaram por estudos dos problemas sociais e ambientais advindos da construção de grandes obras hidrelétricas. Igualmente, houve um avanço na ordem jurídico-legal, em função da Constituição Brasileira de 1988, que permitiu aperfeiçoar dispositivos da legislação ambiental e a institucionalização de instâncias deliberativas tanto de acesso aos territórios de populações tradicionais e aos direitos sociais, étnicos e culturais, quanto à criação de regras para impedir o uso abusivo dos recursos naturais. Os dados de pesquisas, no entanto, nos mostram os difíceis caminhos para implementação desses mecanismos legais.

Este artigo objetiva refletir sobre a construção do campo intelectual, na área de Ciências Humanas, voltado ao entendimento do jogo de relações que envolvem a construção de grandes obras hidrelétricas, no Brasil, e, em especial, na Amazônia, e os conflitos sociais e ambientais em contexto do licenciamento e da construção das usinas, a partir de pesquisas e estudos realizados no Brasil nas últimas décadas. Fizemos uma revisão que ainda é parcial, da literatura produzida sobre hidrelétricas, desastres e judicialização dos conflitos socioambientais no quadro do setor elétrico.

A trajetória dessa produção segue o fio de análise do processo decisório ao licenciamento e à construção das plantas hidrelétricas. Ela nos mostra a diversidade de problemas e de abordagens de pesquisa, pois esses empreendimentos sempre foram marcados por um debate tenso, polêmico e com muitas incertezas. Para uns, essas obras eram vistas como solução às demandas crescentes de energia, e impulsionadoras do processo de industrialização nacional, e de substituição de importações, apoiadas nas crenças de progresso e de desenvolvimento e, para outros, sobressaíam os riscos, a insegurança que uma grande barragem provoca, a mudança no curso do rio, de perda de territórios, de cidades e áreas rurais devastadas, de expulsão de povos indígenas de seus territórios e de ameaças de desastres irreversíveis. Enfim, desenhava-se, nessa perspectiva, o campo temático dos impactos sociais, étnicos e ambientais.

O levantamento de material utilizado nos revelou a importância das pesquisas realizadas no Brasil, da diversidade das instituições, de grupos de pesquisa e de programas de pós-graduação nelas envolvidas, localizadas em diferentes regiões do país. Encontramos trabalhos publicados em muitos periódicos nacionais e internacionais, em livros, em coletâneas, na forma de cartilhas, de documentos oficiais e materiais diversos produzidos por organizações e movimentos sociais. Importante assinalar a produção de teses de doutorado e de 
dissertações de mestrado pois espelham a vitalidade do campo de conhecimento e seus desdobramentos para a sociedade pela formação profissional na temática.

As grandes obras hidrelétricas fazem parte das estratégias governamentais e das políticas nacionais de caráter macro, e com forte poder de intervenção no território. Processos esses têm sido marcados por conflitos sociais e ambientais e são chave para se entender a relação colonial e a natureza da violência nos atos de aplicação dos dispositivos legais pelo Estado, e das práticas das empresas com o territórios e as pessoas que ali vivem, bem como a impunidade legalizada que acompanha a implantação e a operação desses empreendimentos de grande escala.

\section{CONSTRUÇÃO DE UM CAMPO DE CONHECIMENTO E USOS SOCIAIS DA CIÊNCIA}

O campo de conhecimento sobre barragens para produzir energia, por muito tempo esteve adstrito ao domínio técnico voltado à engenharia das obras. Inúmeras disciplinas das engenharias foram criadas, ou adaptadas, nas universidades brasileiras, para atender novas demandas de formação técnica. Igualmente, foram incentivados espaços de debate, de encontros, e de experimentações sobre temas relacionados a solos, regime hídrico, vazão dos rios, materiais e processos técnicos de construção e operação das obras hidrelétricas, entre outros. Esses estudos, inicialmente, não atribuíam relevância a temas relacionados aos impactos ambientais e sociais decorrentes da construção das hidrelétricas com suas barragens, e reservatórios, apesar dessas obras envolverem sempre mudanças enormes no território. Por isso, a resistência de populações atingidas. Os impactos e desartres, como verificado largamente, já começam desde os processos decisórios, de planejamento, de licenciamento, e tendem a se ampliar com a construção e a operação das usinas hidrelétricas.

Mas a engenharia de barragens começou a se desenvolver desde a Antiguidade para responder as demandas de abastecimento e regularização no fornecimento de água para as cidades. Há um savoir faire extraordinário de povos diversos no mundo. Alguns sistemas de abastecimento de água percorriam mesmo grandes distâncias para chegar ao lugar de destino. São antigos também os inventos de processos de irrigação para o controle de inundações. Mas apenas no final do século XX que se inicia o uso da energia elétrica com barragens para gerar eletricidade por meio da potência dos fluxos de água. As experiências com geração de energia a partir dos rios, vista como energia limpa, comparativamente à de derivados do petróleo, mostram que se trata de uma atividade com grandes impactos nos processos produtivos e na vida cotidiana de áreas urbanas e rurais. 
A industrialização nascente no Brasil esteve na base da construção de usinas hidrelétricas. Em 1958 começaram as obras de construção da Usina Hidrelétrica de Furnas, com oito unidades geradoras de energia elétrica ${ }^{2}$. Ela faz o barramento do rio Grande, entre os municípios de São José da Barra e São João Batista do Glória, no estado de Minas Gerais. Era a primeira desse porte no país, gerenciara pela empresa estatal Furnas Centrais Elétricas e pela Companhia Energética de Minas Gerais (Cemig), e localizada na fronteira entre os estados de Minas Gerais e São Paulo. A sua construção era justificada como fundamental para o desenvolvimento do país, pois para o Programa de Metas do presidente Juscelino Kubitschek (1956-1961), a industrialização passou a ser uma das prioridades da política desenvolvimentista do seu governo. Apesar do objetivo em atender o desenvolvimento do estado de Minas Gerais, a energia gerada atenderia a demanda do crescimento nacional. As obras foram iniciadas em 1958 e já era a maior obra em construção na América Latina, sendo inaugurada em $1963^{3}$.

Estudos realizados por Bermann (2013), Fearnside (2011) e Hernandez (2012) mostram o lugar da hidroeletricidade na matriz energética brasileira e as possibilidades que podem ser esgotadas, para geração de energia, sem recorrer a grandes usinas que trazem enormes problemas sociais e ambientais. A primeira

\footnotetext{
A primeira usina hidrelétrica construída no Brasil entrou em operação em 1883, no rio Ribeirão do Inferno, afluente do rio Jequitinhonha, no município de Diamantina (MG). Logo depois, em 1889 seria inaugurada a UH Marmelos-Zero, no rio Paraibúna, no município de Juiz de Fora (MG), sendo a primeira hidrelétrica de grande porte no Brasil e considerada de utilidade pública. Dois anos depois, a UH Parnaíba da empresa São Paulo Light, iniciou a construção de grandes barragens, com 15 metros de altura. Em 1908, foi feita a Usina Hidrelétrica Fontes Velha. Em 1913 entrou em operação a Usina Hidrelétrica Delmiro Gouveia, primeira construída no Nordeste, construída para aproveitar o potencial da Cachoeira de Paulo Afonso no rio São Francisco. Mas em 1954 iniciava o funcionamento a UH Paulo Afonso I, pertencente à Chesf, que era, até então, a de maior porte. Ainda no rio São Francisco, em 1962 entra em operação a Usina Três Matias (MG). A UH Xingó, localizada no município de Canindé, em Sergipe, aproveita também o potencial do rio São Francisco, e entra em operação seu primeiro gerador em 1994. A UH Ilha Solteira, de 1973, e a UH Jupiá, de 1974, ambas no rio Paraná, integram o Complexo Urubupungá, em São Paulo, construídas quase simultaneamente e operadas pela CESP. No Amapá entrou em operação em 1975, a Usina Hidrelétrica Coaracy Nunes, a primeira construída na Amazônia, de pequeno porte explora o potencial hídrico do rio Araguari (MME, 2012).

3 Essas grandes obras são polêmicas e levantam muitas dúvidas. Neste caso, o reservatório era imenso e levou ao deslocamento forçado, com desterritorialização, de cerca de trinta e cinco mil pessoas, muitos afetados em suas condições de trabalho, da perda de terras de agricultura, a áreas de pesca e de outras atividades. A área a ser atingida pela formação do reservatório atravessava trinta e dois municípios de Minas Gerais. Logo fica evidente a necessidade de realizar pesquisas sobre as mega hidrelétricas com recorte analítico sobre os impactos ambientais e sociais observados. E também, os efeitos sobre o ambiente, sendo destacado nos primeiros estudos os problemas relacionados ao alagamento de vastos trechos de floresta, o aumento das taxas de desmatamento, a emissão de gás metano, um dos potencializadores do efeito estufa, a morte de animais e plantas, enfim, questões novas que passaram a ser objeto de pesquisas cientifica.
} 
hidrelétrica construída na Amazônia foi no antigo Território Federal do Amapá, de pequeno porte. Mas as regiões Sudeste e Sul têm larga experiência em Pequenas Centrais Hidrelétricas $(\mathrm{PCH})$, com pesquisas realizadas de larga data ${ }^{4}$. Na realidade, a partir da década de1960 há uma seqüência de mega hidrelétricas construídas no país, caso da UH de Furnas (1963) e a de Sobradinho (1979) ambas no rio São Francisco, a UH de Tucuruí (1984), e a UH Itaipu (1984), sendo esta a maior hidrelétrica com capacidade instalada no mundo. Em 1989 começou a geração comercial da UH de Balbina, no rio Uatumã, município de Presidente Figueiredo (AM). A UH de Jirau, em operação em 2013, e a UH de Santo Antônio, de 2016, ambos no rio Madeira, Estado de Rondônia, provocaram muitos impactos sociais e ambientais. Projetos nacionais considerados prioritários para o Estado, contaram com recursos do Banco Nacional de Desenvolvimento Econômico e Social (BNDES) e a participação de várias empresas organizadas em Consórcios. A UH Jirau, inicialmente estava composta por Suez Energy (GDF Suez, atual Engie) (50,1\%), Eletrosul (20\%), Chesf (20\%) e Camargo Corrêa (9,9\%), tendo se alterada essa composição.

Desde os anos 1990, houve uma retração na construção de grandes hidrelétricas, retomada com a UH de Belo Monte, barrando o rio Xingu (PA) e em operação em 2016. A reordenação na política do setor elétrico passou a favorecer a construção das Pequenas Centrais Hidrelétricas (PCHs) como alternativa para geração de energia ${ }^{5}$. E, a partir da crise ocorrida em 2001 houve um aumento significativo na construção de $\mathrm{PCHs}^{6}$. Estudos sobre os impactos sociais e ambientais têm conformado um campo de análise para mostrar os problemas críticos provocados por esses empreendimentos que são muito numerosos no país, embora o peso dos danos seja menor, se analisado cada PCH de per si. No entanto, há certos rios onde foram construídas inúmeras PCHs, gerando grandes impactos sociais e ambientais.

$4 \quad$ Na década de 1950, houve crescimento significativo de energia também devido a instalação de PCHs. O estado de Minas Gerais tem o maior parte das PCHs do país. Houve um crescimento enorme. Na década de 1940 existiam centenas de pequenas centrais construídas com capital nacional. Dispositivos legais proibiam o uso do capital estrangeiro nesse setor, mas a partir dos anos 1950, quando essas centrais passaram a ser desestimuladas. Na década seguinte muitas foram desativadas. Voltariam a ter incentivos públicos na década de 1990 passando a fazer parte da matriz energética do país com justificativas de ampliação da capacidade de geração de energia em todo o território nacional.

5 Segundo a Agência Nacional de Energia Elétrica (ANEEL), a energia que move o país - capacidade instalada de 133,9 mil MW - é proveniente de 202 usinas hidrelétricas, 1.935 termelétricas, 228 usinas eólicas, 2 usinas nucleares, 487 pequenas centrais hidrelétricas, 497 centrais geradoras hidrelétricas e 311 usinas solares (MME, 2017).

6 Ver a Lei no 10 438/2002, na qual as Pequenas Centrais Hidrelétricas integram o Programa de Incentivo às Fontes Alternativas de Energia Elétrica. 
Os estudos dedicados ao planejamento do desenvolvimento regional, e da análise econômica, com um olhar voltado para o crescimento, viam nesses empreendimentos um fator para impulsionar as dinâmicas macroeconômicas e os processos de industrialização a partir de teorias de polos de desenvolvimento que iriam, enfim, levar o progresso às regiões periféricas. Os princípios são de um planejamento autoritário e as práticas coloniais quando se trata de uma relação com regiões que eles, os gestores do planejamento nacional, veem como periferia (ACSERALD, 1991). As primeiras grandes usinas hidrelétricas planejadas no país foram pensadas, conjuntamente, com a instalação de complexos mínerometalúrgicos, como é o caso das hidrelétricas do Amapá e de Tucuruí. Os impactos sociais e ambientais provocados por essas grandes obras, acabaram por se tornar um tema de interesse, de debate nacional e internacional, e de pesquisas. Aos poucos ficou clara a necessidade de abordagens interdisciplinares, numa perspectiva mais ampla das áreas de Ciências Humanas, mas também no campo das ciências exatas e das ciências naturais.

É possível considerar que já nos anos 1980 começa a ser construído esse campo temático, inclusive alguns estudos adotam uma perspectiva interdisciplinar, com contribuições trazidas das áreas disciplinares. Um esforço da ciência para repensar as perspectivas teóricas, os métodos e os processos de conhecimento. $\mathrm{O}$ avanço na produção de um conhecimento crítico e reflexivo, e contextualizado, foi possível graças a um debate de coletivos de pesquisadores e movimentos sociais sobre os problemas sociais e ambientais concretos, que se passavam no território, provocados por esses empreendimentos. E, por isso, um conhecimento relacionado à prática política pois os atores locais se apropriavam de possibilidades de influenciar decisões tomadas em outros patamares do planejamento do setor elétrico, e de diversas escalas da gestão pública e das empresas e consórcio construtores. Se não influenciar, pelo menos resistir e dar visibilidade a situações limites como a supressão de direitos que tem acompanhado as grandes obras no país.

As questões sociais, étnicas e ambientais começaram a ser contempladas, inclusive porque o próprio desempenho técnico-econômico de muitos aproveitamentos hidrelétricos se via ameaçado pela deterioração ecológica dos reservatórios. A partir do final dos anos 1970 e início dos anos 1980, os deslocamentos compulsórios, a destruição dos territórios, o fluxo intenso de migrantes, a perda de qualidade da água e uma série de outros problemas relacionados ao território do qual depende a vida de povos indígenas, ribeirinhos, comunidades tradicionais, mas também das pessoas que vivem das cidades e nos povoados. Toda essa resistência, em diferentes lugares do país, com a mobilização 
das populações atingidas, acabou trazendo as grandes barragens para a pauta dos estudos de cientistas sociais.

É importante ressaltar a contribuição das universidades, de institutos de pesquisa, de associações científicas, de organizações profissionais e populares, na construção desse campo de conhecimento. Compreensão sobre as relações entre grandes obras de infraestrutura e as dinâmicas de acumulação de capital. Por perspectivas diferentes, mas com um olhar próximo ao da teoria crítica, e da práxis, no âmbito das Ciências Sociais, os desdobramentos desse processo, passaram a ser analisadas por campos distintos da antropologia, da sociologia, da geografia, do direito, da ciência política, do planejamento urbano e regional, da economia, e da ecologia. Igualmente coincide com a ampliação dos programas de pós-graduação, sua capilaridade regional, fomentando expressivo portfólio de teses de doutorado e de dissertações de mestrado sobre o campo. Assinale-se, ainda, que essa dinâmica intelectual se expressa na produção de livros, coletâneas, artigos, na realização de encontros científicos e políticos. Um processo que se estende até hoje na construção da área temática.

O conceito de território é importante, pois se trata de lugares de pertença, de identidades, e que são transformados, devastados e acabam por alterar, completamente, a vida das pessoas que ali vivem, pois são lugares preenchidos de sentidos, significados, memória e história. Mas também de qualquer outra forma de vida uma vez que animais e vegetais são desalojados de seus habitats, e não poucas vezes, mortos, extintos com suas espécies, o que significa também perda de memória da natureza, uma vez que a história do planeta se inscreve pela memória das espécies, inclusive da espécie humana que um dia pode desaparecer. E sua história também.

O rio Tocantins com a hidrelétrica de Tucuruí, perdeu mais de 30\% de suas espécies. Igualmente perda pela enchente do imenso e inútil reservatório da UH de Balbina, um escândalo silenciado. Animais dizimados e floresta afogada no reservatório da usina. A natureza tem vida, e esses grandes empreendimentos nem sequer levam em conta sua reprodução física e que esta faz parte da cadeia ecológica, alimentar e reprodutiva. Os estudos tem mostrado que os impactos sociais e étnicos são de alta gravidade pois tem levado ao ecocídio com a destruição dos biomas e ao genocídio que é a morte física e cultural dos grupos sociais. Isso porque as consequências das mega hidrelétricas são devastadoras nos territórios. Em geral, os projetos de hidrelétricas alteram a configuração territorial e com a finalização da obra, continuam a ocorrer processos de expropriação de grupos e pessoas, violência física e simbólica, 
desastres e tragédias como as observadas em plantas de mineração em Mariana (MG) e Barcarena (PA). Esses empreendimentos vêm acompanhados de outros, de setores diferentes, como ocorre na Amazônia, com o avanço de commodities agrícolas e minerais, e obras de estradas, de portos, de ferrovias, impactos múltiplos e por isso com efeito de transbordamento ${ }^{7}$ (GUDYNAS, 2015), como verificado no território onde foi construída a Usina Hidrelétrica de Belo Monte, ou Belo Monstro, como preferem alguns moradores da região.

Os dados da Tabela 1 coletados junto ao Banco de Teses da Capes com o recorte temporal de 1996 a 2018, não nos permite avaliar a produção anterior e esse período, embora tenham sido muito importantes sobretudo das dissertações de mestrado, na construção do debate intelectual. É notável observar o montante de 386 teses, com participação crescente também nas três grandes áreas. Em particular destacamos humanidades e ciências naturais (inclui biologias e ciências da saúde) considerando a constituição inicial de um campo sob domínio das engenharias. É também expressiva a distribuição das 24 teses concluídas entre 1996 a 2001, pelas três grandes áreas. A transversalidade do tema aparece na formulação dos problemas de pesquisa pelos seus autores.

Tabela 1 - Produção de teses de doutorado sobre hidrelétricas no Brasil (1996-2018)

\begin{tabular}{c|c|c|c|c|c}
\hline \multirow{2}{*}{ ÁREA } & \multicolumn{5}{|c}{$\begin{array}{c}\text { TESES DE DOUTORADO DE 1996-2018 } \\
\text { (ano de defesa) }\end{array}$} \\
\cline { 2 - 6 } & $\begin{array}{c}\text { De 1996 } \\
\text { a 2001 }\end{array}$ & $\begin{array}{c}\text { De 2002 } \\
\text { a 2007 }\end{array}$ & $\begin{array}{c}\text { De 2008 } \\
\text { a 2013 }\end{array}$ & $\begin{array}{c}\text { De 2014 } \\
\text { a 2018* }\end{array}$ & $\begin{array}{c}\text { Total de } \\
\text { 1996 a 2018 }\end{array}$ \\
\hline HUMANAS & 6 & 26 & 39 & 65 & 136 \\
\hline $\begin{array}{c}\text { CIÊNCIAS NATURAIS/ } \\
\text { VIDA }\end{array}$ & 7 & 30 & 28 & 45 & 110 \\
\hline $\begin{array}{c}\text { CIÊNCIAS DA TERRA } \\
\text {-ENGENHARIAS }\end{array}$ & 11 & 14 & 42 & 73 & 140 \\
\hline TOTAL POR PERÍODO & 24 & 70 & 109 & 183 & 386 \\
\hline
\end{tabular}

Fonte: Banco de Teses, Capes/Ministério de Educação ${ }^{8}$

* Os dados relativos ao ano de 2018 são parciais

As grandes obras de hidrelétricas são acompanhadas de desmatamento, embora isso não fosse contabilizado pelos empreendimentos como riscos e perdas. $\mathrm{O}$ mesmo em relação às áreas de inundação decorrentes da barragem dos rios, chamado de reservatórios. Atualmente, somamos na Amazônia mais de 1 milhão de hectares de terras que foram inundados. O reservatório de Tucuruí ocupa 180 mil hectares, e de Belo Monte, 64.100 hectares.

8 O levantamento procedido no Banco de Dados de Teses da Capes e utilizados para fins deste trabalho considerou apenas como palavra-chave "hidrelétrica', podendo, portanto, estar sujeito a modificações caso se utilize outras palavras-chave ou mecanismos diferentes de busca. 
As discussões promovidos por associações científicas das humanidades passaram a ter, cada vez mais, participação de pesquisadores e profissionais das ciências da vida e das engenharias para discutir problemas socioambientais. Momentos importantes na produção de espaços de debates acadêmicos e de natureza política pelo estranhamento do olhar formado em disciplinas diferentes, mas desafiado à percepção da complexidade exigida pela observação dos problemas.

A produção de conhecimento realizada no âmbito dos Programas de pós-graduação de doutorado e de mestrado tiveram espaços de debate nos Congressos Científicos e nos Encontros das Associações Nacionais de Pesquisa e Pós-graduação, entre outras na ANPOCS, na SBS, na ABA, na ANPUR, na ANPEG, na ANPPAS e na ANPED. A análise da apresentação de trabalhos nos Grupos de Trabalho e Sessões Temáticos revela o interesse pelos estudos e desdobramentos múltiplos desses grandes projetos de infra-estrutura elétrica.

Entre esses momentos, é importante ressaltar os Encontros de Ciências Sociais e Barragens, realizado já há 15 anos. Certamente inauguraram uma nova etapa, como espaço para reunir, sistematizar e comparar os resultados de pesquisa. Por iniciativa de Carlos Vainer e do Instituto de Pesquisa e Planejamento Urbano e Regional (IPPUR-UFRJ), no Rio de Janeiro, foi formada, estritamente para esse tema, uma rede de pesquisadores de todo o país que acompanha até hoje, de certa forma, essa experiência do debate interdisciplinar e interescalar. No I Encontro de Ciências Sociais e Barragens, realizado no Rio de Janeiro em junho de 2005, foram apresentados 170 trabalhos de professores, estudantes, técnicos de instituições governamentais e de empresas privadas, e de representantes de movimentos populares e organizações não governamentais.

O II Encontro de Ciências Sociais e Barragens foi realizado na cidade de Salvador, em novembro de 2007 e conseguiu ampliar o campo de abrangência do debate e da articulação acadêmica, sendo realizado, ao mesmo tempo, o I Encuentro Latinoamericano de Ciencias Sociales y Represas. O evento recebeu profissionais e estudantes de vários países latinoamericanos interessados no debate concernente ao tema, reuniram cerca de 400 pesquisadores, com mais de 200 trabalhos e comunicações. O III Encontro Nacional de Ciências Sociais e Barragens/ II Encuentro Latino-Americano Ciencias Sociales y Represas, foi realizado em Belém, em novembro de 2010, sediado pelo Núcleo de Altos Estudos Amazônicos (NAEA/UFPA), com 200 trabalhos apresentados nos Grupo de Trabalho e Mesas Redondas, e cerca de 500 participantes, inclusive muitos povos indígenas e integrantes de movimentos sociais e atingidos por barragens. Também foi importante a vinda de colegas e estudantes de outros países da América Latina. O IV Encontro Internacional de Ciências Sociais e Represas ocorreu em Chapecó, 
estado de Santa Catarina, lugar privilegiado para o acesso de pesquisadores de países vizinhos. O evento foi preparatório também daquele que viria a ser o primeiro da rede de pesquisadores a ser realizado fora do Brasil. O $V$ Encuentro Internacional Ciencias Sociales y Represas ocorreu em Santiago, Chile, em outubro de 2018. O caráter latino-americano do evento ressalta a relevância da cooperação acadêmica continental, tanto mais que se acelera a construção de hidrelétricas em muitos países da América Latina o que coloca na agenda de discussão, temas como o planejamento e a implantação de grandes projetos binacionais e, mesmo, em alguns casos, de dimensão continental. Chama atenção a privatização e a presença crescente de plantas sendo construídas sobre a chancela de empresas americanas ou chinesas, entre outros interesses do movimento de economia global, ávidos pelo controle não somente dos recursos energéticos, mas sobretudo da água.

Encontramos no Banco de Teses da Capes, na área de Humanidades, 136 teses sobre hidrelétricas registradas no período de 1998 a 2018. As primeiras universidades que titularam doutores no tema foram a Universidade de São Paulo, a Universidade do Rio de Janeiro e a Universidade Estadual de Campinas. Porém, no correr desse intervalo, as universidades com maior número de teses concluídas foram: a USP, com 23 teses, a UNESP com 14, a UnB com 12, a UFPA com 12, a Unicamp com 8 e a UFRJ também com 8 teses. Inúmeros Programas de Pós-graduação no país contribuíram na construção do debate sobre essa área temática. O Gráfico 1 nos permite acompanhar o movimento crescente da produção de teses no intervalo de 1998 a 2018.

Gráfico 1 - Evolução de teses de doutorado concluídas na Área de Humanidades por ano (1998 - 2018)

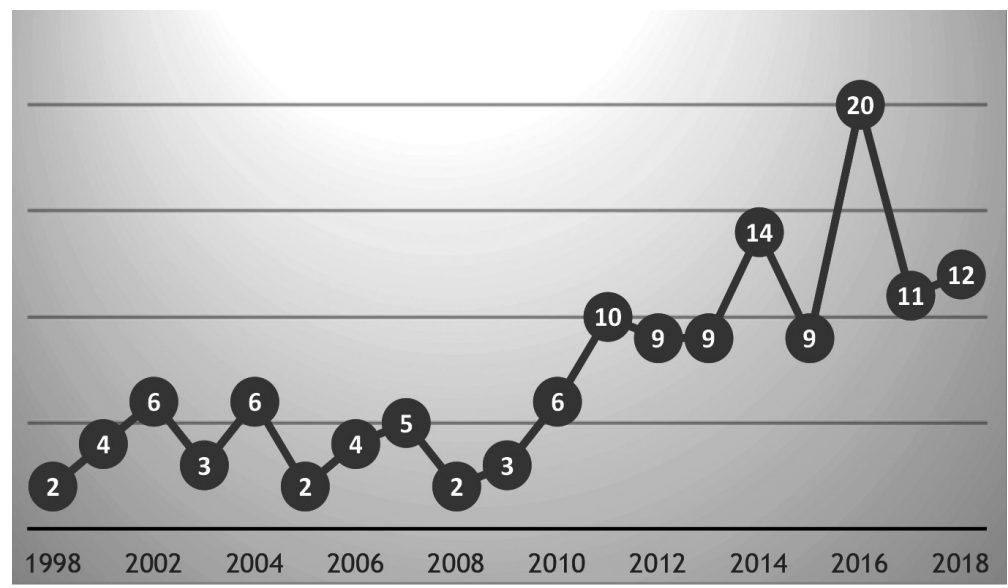

Fonte: Banco de teses da CAPES/MEC.

Obs. Os dados referentes ao ano de 2018 são parciais. 
Foi importante na construção desse campo de conhecimento a posição consciente dos usos sociais da ciência, sobretudo em temas que tangenciam a vida, humana e da natureza. Um conhecimento que está sendo produzido na prática social com os sujeitos atingidos pelos empreendimentos e que trazem à academia a possibilidade de uma outra forma de fazer ciência, a partir da inversão do olhar, ao reconhecer os usos sociais do próprio conhecimento enquanto uma dimensão da criação coletiva.

\section{LINHAS TEMÁTICAS DOS ESTUDOS SOBRE HIDRELÉTRICAS NAS CIÊNCIAS SOCIAIS}

Os estudos realizados sobretudo a partir da década de 1980, se curvam sobre algumas questões que pretendem dar conta da complexidade que envolve a construção desses projetos de grande escala.

Observou-se, a partir da produção bibliográfica consultada, a conformação de sete eixos temáticas que identificamos como: 1 - Planejamento, desenvolvimento e políticas nacionais; 2 - Empresas, empreendimentos e mercado; 3 - Mobilidade espacial e do trabalho; 4 - Transformações no território e deslocamento forçado; 5 - Direitos e territórios de povos indígenas; 6 - Impactos ambientais; 7 - Conflitos e estratégias de resistência.

A maior parte das pesquisas desdobram-se em outras questões ao longo de sua realização e observa-se um campo atravessado por dinâmicas complexas ao entendimento e marcado por relações políticas. A partir dos eixos citados, a maior parte das pesquisas se concentra sobre as seguinte questões: a) processos de decisão, planejamento e formulação de políticas governamentais para o setor elétrico; b) estratégias de reprodução do capital e formação de conglomerados, corporações e consórcios; c) transformações socioeconômicas e impactos sociais, ambientais e étnicos; d) mobilização, imobilização e desmobilização da força de trabalho e composição do mercado de trabalho; e) imaginários e memória; f) subjetividades e processos de reparação; g) deslocamentos compulsórios e processos de expulsão da terra de povos indígenas, quilombolas, camponeses, pescadores e ribeirinhos; h) campesinato, problemas fundiários e resistência camponesa; i) movimentos sociais e construção de identidades; j) mudanças nas cidades e emergência de novas formas de controle do espaço urbano; k) precarização da saúde e do meio ambiente, a exemplo das pesquisas sobre proliferação e persistência de mosquitos e de outras pragas em reservatórios de usinas hidrelétricas; 1) desmatamento e produção de gases de efeito estufa; m) emissão de gases e mudanças climáticas; n) violência e impunidade associada ao Estado e às políticas desenvolvimentistas; o) ameaças às Terras Indígenas, 
aos Territórios Quilombolas, às Unidades de Conservação e também às terras destinadas a assentamentos agrários.

Como em outras áreas, é possível identificar grupos de intelectuais formadores de um dado campo de conhecimento, pela sua contribuição no mundo das ideias, de seu trabalho conceitual e crítico, seja na escrita, nos debates, ou na articulação institucional, e política portanto, com fins de continuidade dos processos. No tema tratado, cabe ressaltar a capilaridade da produção de conhecimento em todas as regiões do país. E de formadores de opinião, como aqueles que estiveram presentes, com continuidade, na construção da área.

Dos estudos, cito algumas referências nominais, tendo o cuidado de esclarecer não se tratar de um relação exaustiva. Assim, sobretudo consultando os dados dos Encontros de Ciências Sociais e Barragens, já referidos, e das publicações consultadas, arrolamos trabalhos dos seguintes autores que estudaram as hidrelétricas que foram construídas em várias regiões do país e, muitos deles, orientaram teses de doutorado e dissertações de mestrado em temas relacionados à hidrelétricas: Osvaldo Sevá, Célio Bermann, Lygia Sigaud, Carlos Vainer, João Pacheco de Oliveira, Philip Fearnside, Silvio Coelho, Edna Castro, Jean Hébette, Guiomar Inez Germani, Sônia Magalhães, Alfredo Wagner de Almeida, José Sérgio Leite Lopes, Francisco Del Moral Hernandez, Eduardo Viveiros de Castro, Rosa Acevedo, Eliane Cantarino, Parry Scott, Maria Auxiliadora Ferraz de Sá, Lúcio Flávio Pinto, Diana Antonaz, Felício Pontes Jr., Manuela Carneiro, Mauro Almeida, Stephen G. Baines. Iara Ferraz, Maria José Reis, Gustavo Ribeiro, Franklin Rothman, Andréa Zhoury, Raquel Oliveira, Marcos Zucarelli, Glenn Switkes, Bruce Albert, Luiz Fernando Novoa, Antônio Carlos Magalhães, Guilherme Carvalho, Telma Parente e Cyntia Miranda.

Os projetos de grande escala são marcados por três dimensões estruturais e, portanto, sempre presentes e não concorrentes, como assinala Ribeiro (1987). O gigantismo pela enorme quantidade de fluxos de capital e trabalho, o isolamento que requer acoplar outros processos organizacionais e logísticos, e o caráter temporário que corresponde à intervenção intensiva seguida de desmobilização dessa forma de produção. O gigantismo é ressaltado de imediato na própria construção, com grandes obras de engenharia que se impõem no espaço, imensas. Pelo seu tamanho exigem, necessariamente, enormes quantidades de capital e de trabalho" ". Significa remover terras e águas em grandes quantidades, e transformar o território de forma rápida e irreversível.

\footnotetext{
Murphy (1983, VII, 2) e Leonhard (1982, p. 113) consideram os Projeto de Grande Escala/ PGE como empresas de capital intensivo, variando de US\$ 100 milhões até muitos bilhões de dólares para cada projeto, empregando, com frequência, mais de 10 mil pessoas (apud RIBEIRO, 1987) .
} 
Talvez na Amazônia tenham sido acerbadas as dimensões de enclave colonial, da violência e do conflito que tem acompanhado a construção de todas as mega hidrelétricas. Ocorre em geral uma grande mobilização de trabalhadores e empresas que acabam por permanecer na região, sendo ator determinante do avanço sobre novas fronteiras territoriais motivando conflitos com agentes da pequena produção familiar, povos indígenas e quilombolas, ampliando a dinâmica na fronteira do desmatamento ${ }^{10}$. Nesse quadro trata-se de dimensões que são complementares, mas encontradas nas grandes hidrelétricas construídas na Amazônia. Cabe resultar que as pequenas e médias usinas hidrelétricas trazem inúmeros problemas, como mostram as pesquisas e também os debates realizados, sobretudo pela alteração sequencial do rio com várias $\mathrm{PCH}$ instaladas, transformando irreversivelmente o rio, ou de sua poluição, dos riscos de inundação, de perda da qualidade da água e de privatização dos espaços.

O portfólio de pesquisas realizadas nas áreas de humanidades, de engenharias, da biologia, saúde e ecologia, é muito expressivo e se reporta a problemas sobretudo locais que tem sistematicamente escapado à análise de riscos apresentada pelas empresas.

O exame minucioso destes processos mostra o descompasso nos estudos sobre os temas acima mencionados. Magalhães, Brito e Castro (1996), na introdução ao livro Energia da Amazônia, reconhecem o esforço da pesquisa que resgata a análise das condições pré-existentes à ação do Estado, somente possível de serem apreendidas por meio de uma perspectiva que privilegie os estudos locais, a experiência social e, consequentemente, o resgate das bases sociais da reconstrução do passado e da criação de expectativas futuras. Os estudos mostram ainda que na construção da resistência em defesa de seus territórios, os povos indígenas e os camponeses recorrem a parâmetros de sua conformação política da memória e de sua história. Esses grupos sociais e étnicos que habitam territórios atualmente pretendidos pelos projetos hidrelétricos construíram uma história, com organização social e percepção do mundo ancorada em sua cultura

10 Um dos temas mais estudados relacionados a grandes obras hidrelétricas foi o de Estado e políticas de desenvolvimento uma vez que, ao interior do Estado, se travava uma disputa política que envolvia a decisão de construir ou não grandes usinas hidrelétricas, onde as construir, os meios, etc.e depois questões relacionadas a competências de gestão, modelo de financiamento, e finalmente os interesses em jogo, econômicos e ambientais sobre o que representava essa grande obra sobre transformação no território. As licenças também envolvem muitos procedimentos e órgãos, instituições ao interior do Estado. Citamos alguns trabalhos como o de Maria Celina d'Araújo. Amazônia e desenvolvimento à luz das políticas governamentais: a experiência dos anos 50. In: Revista Brasileira de Ciências Sociais, n. 19, ano 7, jun. 1992; de Alfredo Wagner Berno de Almeida. O intransitivo da transição: o Estado, os conflitos agrários e a violência na Amazônia. Organizadores LENA, Phillipe e OLIVEIRA, Adélia. Amazônia: a fronteira agrícola: 20 anos depois. Belém: MPEG, 1991, p. 259-290. 
e na relação com a natureza. Atuam como sujeitos com saberes contextualizados e, por isso, interlocutores em qualquer ação que incida sobre seus modos de vida.

Uma das preocupações centrais nos estudos sobre grandes barragens no Brasil tem sido compreender as transformações socioeconômicas em territórios transformados pela sua implantação (GERMANI, 2003). Trata-se de entender os fluxos do capital e a composição das empresas organizadas em conglomerados, ou consórcios, e a movimentação de recursos técnicos, competências, empresas médias e pequenas, terceirizadas ou não, e de trabalhadores, além de que esses grandes projetos requererem um volume enorme de recursos financeiros.

Essas transformações têm provocado um fluxo intenso de deslocamento de trabalhadores de distintas áreas do país em direção a esses projetos por alguns anos, podendo permanecer até a sua conclusão. Um grande projeto pode absorver, em momento de pique, até 20.000 ou 30.000 trabalhadores, como observado na construção de usinas de Tucuruí (LEITE LOPES, 1996; HEBETTTE, 2004; VAINER, 2008), de Belo Monte (FEARNSIDE, 2011, 2015; SEVÁ, 2005a, 2005b; OLIVEIRA, 2014; CASTRO et al., 2014; CASTRO, 2015; MAGALHÃES, 2005; NASCIMENTO, 2016), Santo Antônio e Jirau (NOVOA GARZON, 2015; ALMEIDA, 2009; CARVALHO; 1996). São importantes ainda os estudos realizados sobre a dinâmica de atores sociais no território central de intervenção e no seu entorno, processos de resistência, de luta e organização de movimentos, a exemplo do Movimento dos Atingidos por Barragens (MAB), face às estratégias da reprodução do capital e ao papel do Estado e de suas políticas voltados para assegurar os grandes de energia.

As ameaças físicas e culturais à integridade dos povos indígenas e se seus territórios têm sido correntes no processo de instalação de usinas hidrelétricas na Amazônia (CARNEIRO; BARBOSA, 2018; ALBERT, 1995; ISA, 2010). Inúmeros povos tem sido massacrados e subjugados a processos violentos, como os Waimiri Atroari, pela Usina Hidrelétrica de Balbina com deslocamento forçado. O povo Gavião foi uma das etnias atingidas, e deslocada compulsoriamente para outra terra, com a construção da Usina Hidrelétricade Tucuruí. Em quase todas as grandes obras construídas na Amazônia temos os registros dolorosos,e ainda porque são processos que continuam e se tornam agudos com as políticas nacionais atuais de infra-estrutura, e com o aumento das usinas em construção ou no panejamento estatal. O deslocamento forçado conforma um campo específico de situações em que grupos sociais e étnicos são obrigados a deixar seus territórios, lugares históricos ou de ocupação imemorial, por motivos de constrangimento externo, que pode ter natureza variada, desde a ameaça à 
integridade física e cultural por mecanismos coercitivos e intimidatórios, por processos de criminalização e, até à morte ${ }^{11}$.

Inúmeros estudos etnográficos mostraram esses movimentos de deslocamento compulsório de grupos indígenas em vários empreendimentos, como a Hidrelétrica de Tucuruí (FERRAZ, 1996; MAGALHÃES; BRITO; CASTRO, 1996); Belo Monte no rio Xingu (SEVÁ, 2005a, 2005b; BELTRÃO; OLIVEIRA; PONTES JUNIOR, 2014). Na construção das hidrelétricas de Tucuruí, no Pará (FERRAZ, 1996; FERRAZ; VIVEIROS DE CASTRO, 1986/87); da hidrelétrica de Balbina, no Amazonas, com o deslocamento compulsório de Waimiri-Atroari (BAINES, 1996; RODRIGUES; FEARNSIDE, 2014) nos processos mais recentes e que vem ainda ocorrendo com os Indios Kaiapó, em Altamira, no Pará, conforme assinalado por Magalhães (2005) e Sevá (2005b). Os índios Munduruku estão mobilizados em defesa de seus territórios devido à construção da Hidrelétrica de Teles Pires, no Mato Grosso, que atingiu com grande impacto a sua Terra Indígena, os rios e os territórios de trabalho, da caça, agricultura e pesca. Esse mesmo povo Munduruku está sob ameaças devido aos projetos de construção de grandes obras hidrelétricas no rio Tapajós, no Pará, associadas à instalação de portos e à duplicação da rodovia CuiabáSantarém, que incidem sobre seus territórios. O movimento de resistência chamado Tapajós Vivo, iniciou várias ações de denúncia e contestação em 2015. Em 2016, organizou a II Caravana em defesa do rio Tapajós que reuniu, na cidade de Itaituba, povos indígenas e diferentes segmentos de trabalhadores do campo e da cidade com cerca de 1.000 participantes, para discutir mobilizações e estratégias políticas de enfrentamento e resistência à médio e longo prazos.

Os estudos sobre o campesinato em regiões atingidas por barragens, do Rio Grande do Sul, Paraná, Bahia, Minas Gerais, Sergipe até à Amazônia, retratam as dimensões referidas aos territórios apropriados pelos canteiros de obras e pela área dos reservatórios, de grandes proporções, cuja cota do rio ${ }^{12}$ sempre foi um elemento de imprecisões, de tensão. e de conflitos (SIGAUD, 1986; LEITE LOPES; SIGAUD, 1986; SCOT'T; FERRAZ DE SÁ, 1995). Formação de coletivos de resistência com a participação ampliada de segmentos camponeses, atingidos por grandes projetos de energia e mineração (CARVALHO, 1996; HÉBETTTE, 2004; CARNEIRO, 1997).

11 Outra categoria analisada nesses processos é a de refugiados do desenvolvimento, sinalizando grupos que são forçados a se deslocarem para lugares mais distantes, cujas causas são os programas ou os projetos instaurados no âmbito das políticas desenvolvimentistas.

12 Refere-se ao nível do rio informado pela empresa, ou ao limite para redefinição das margens do rio, alteradas pela barragem. A expectativa, marcada de tensão e sofrimento por parte de moradores urbanos, rurais e de grupos étnicos, é que a água do rio, ao definir as novas margens, tenham deixado menos danos sociais e ambientais. 
Apoiadas nas clássicas lições sobre a reprodução social do campesinato, alguns trabalhos mostram as particularidades históricas desse campesinato. Pesquisas realizadas indicam as decisões tomadas em situações de deslocamento compulsório para outros territórios com ou sem loteamento agrícola, caso da obstrução da barragem de Sobradinho, e do Reservatório da Hidrelétrica de Tucuruí, em ambos os casos, os reservatórios extrapolaram todas as "cotas" anunciadas pela engenharia do projeto como certas, alagando territórios e levando ao fundo vilas e cidades, áreas de agricultura familiar, cemitérios, paisagens que faiam parte de um mundo afetivo e sagrado, submergidos junto com a floresta. A resistência camponesa em Tucuruí realizou acampamentos com mais de duas mil pessoas, e meses de negociação com a empresa. Evidenciando o desaparecimento social de grupos de camponesa provocado pela construção de Sobradinho, Daou (1996) discute a composição do campesinato e os conceitos tradicionalmente utilizados pelo setor elétrico que obscurece o sentido e a natureza desses grupos. Os trabalhos de Hébette (2004) sobre a reprodução camponesa orientam a análise na direção de novas áreas de fronteira e do aparecimento de sistemas agroflorestais mais complexos por parte da pequena produção familiar. No Alto Uruguai, sul do Brasil, os impactos provocam reações das populações locais ameaçadas em seu modo de vida (REIS, 1996).

Justamente pela capacidade de mobilização de mão-de-obra para lugares muitas vezes distantes, de difícil acesso, e com serviços de infraestrutura em geral deficientes que pioram com o aumento rápido da densidade populacional, a instalação dos projetos de grande escala produzem efeitos devastadores nas áreas rurais e urbanas. Em nenhum caso, no Brasil, observou-se a aplicação de um plano preparatório, e discutido com os atores locais sobre os desdobramentos da obra e seus impactos. À chegada massiva de empresas e de trabalhadores que acompanham essas grandes obras, ocorre um aumento imediato do valor do solo urbano, aquecimento do mercado de terras, expansão e aparecimento de novos bairros e precariedade dos serviços urbanos que além de serem deficientes, tornaram-se sobrecarregados. Muitos destes decorrem de divisões sociais relativas ao aceite ou não do grande projeto que altera a vida das pessoas na cidade, nas áreas rurais e nos territórios étnicos, enquanto espaços comuns e compartilhados (RIBEIRO, 1991; CASTRO, 2012).

Os processos de integração de mercado no mundo globalizado expõem, de forma mais evidente, as estratégias globais que se materializam nos espaços locais. O movimento de globalização e a crescente concentração de mercados tem alterado, mesmo em regiões com histórico de integração de mercado, a dinâmica 
da mobilidade da força de trabalho. Vários casos examinados (RIBEIRO, 1991; LEITE LOPES, 1996; CASTRO, 2010) dão conta da estreita relação entre poder e território e também sobre os processos de trabalho que se alteram no tempo e espaço com a imobilização e a dispersão da força de trabalho. Os estudos sobre os agentes econômicos revelaram as estratégias das grandes empresas e de instituições financeiros e a percepção destas sobre o território e a sociedade, a exemplo das estratégias patronais de imobilização da força de trabalho pela moradia ou pela impossibilidade de acesso a espaços externos à obra. Fato corrente e recentemente observado na construção das Usinas Jirau e Santo Antônio, no rio Madeira, estado de Rondônia, com grandes alojamentos em áreas de mata, distante dos circuitos de comunicação e transporte, trabalhadores imobilizados, pelas empresas responsáveis pela construção dessas hidrelétricas.

A intensa mobilidade espacial de trabalhadores nas áreas de fronteira econômica na Amazônia, seguindo as grandes obras ou outras oportunidades de trabalho (CASTRO, 1989), ainda que expresse uma instituição social móvel, na observação de Leite Lopes (LEITE LOPES, 1996), trata-se da introdução de modelos sofisticados de gestão do trabalho, mas sob formas de dominação e controle que se estendem do canteiro da obra àvida privada. Processos observados em todos os grandes projetos que tendem a se expandir, na Amazônia, desse início de século, nos empreendimentos de siderurgia, Albras, Alunorte, Alumar, nos de mineração como o Ferro Carajás, a Mineração Rio do Norte, ou na construção da Ferrovia Carajás e do Porto de Itaqui, e nas usinas hidrelétricas ${ }^{13}$. São acionadas, recorrentemente, as estratégias de imobilização da força de trabalho pela moradia, diferenciada socialmente (alojamento, residência) e com elementos ou modelos de distinção presentes, seja no Núcleo Urbano da Serra do Carajás, na Vila dos Cabanos, em Barcarena, na cidade de Porto Trombetas, no rio Trombetas, e no Núcleo urbano de Turucuí.

Uma das questões que se colocara nos anos 1980 era de saber a natureza das mudanças verificadas na gestão empresarial nos setores mínero-siderúrgico e de hidreletricidade, no Brasil. Pesquisas realizadas nas plantas das grandes empresas de mineração e siderurgia revelaram que foram experimentadas, desde o final dos anos 1970, novas práticas de gestão inspiradas no que estava sendo chamado de restruturação produtiva, ou ainda, produção flexivel, orientado nos empreendimentos do setor mineral, sobretudo para modernização da gestão do trabalho, sem tocar na conversão tecnológica das plantas de produção.

13 As grandes empresas no Brasil têm atuado nos mercados latino-americanos e africanos por meio de investimentos, e o BNDES tem sido um dos principais agentes nesse processo, notadamente na construção de grandes obras de infraestrutura, a exemplo de usinas hidrelétricas. 
As empresas-mãe, do ramo da mineração e siderurgia, iniciaram a implantação do Círculos de Controle de Qualidade (CCQ), com os operários, sob a liderança da Companhia Vale do Rio Doce (hoje VALE), Albras-Alunorte (hoje Hydro) associadas a capitais estrangeiros, notadamente japonês no caso da siderurgia de alumínio no município de Barcarena. Tais mudanças são percebidas pela introdução de novos padrões de gestão, de racionalidade do tempo e do espaço, nos processos de modernização empresarial e adaptação à restruturação flexível.

Os discursos de desenvolvimento e de modernização se impõem pelos vínculos com as ideias de progresso e nação. É a isso que se refere Almeida (2009) ao explicitar de quem são as iniciativas e quais os dispositivos acionados por agentes para legalizar o ilícito. São os centros de poder em nível nacional e os organismos multilaterais, ou seja, as fontes financiadoras internacionais ${ }^{14}$.

Antonaz (2005) faz um excelente balanço do setor elétrico e das instituições e de seus personagens, inclusive de militantes do setor cujas bandeiras associam energia, desenvolvimento e progresso, e de empresas estatais e de instituições de pesquisa que formulam essas idealizações. Instituições do setor elétrico organizadas e com um saber acumulado de longa duração tem fomentado conceitos e correntes de pensamento, como assinala a autora, de tal modo que diferentes posições no mesmo campo se expressem com certo consenso, apesar de diferenças, permitindo que seja produzida uma linguagem com princípios comuns.

A Eletrobras, e em especial a Petrobras, desempenharam em todas essas décadas, papel fundamental na difusão de um ideário de energia limpa. O biodiesel foi incentivado como tecnologia livre de impactos ambientais, embora se saiba que os agrotóxicos fazem parte integrante do milagre da agricultura intensiva. Além do que a monocultura gera impactos sociais, fundiários e ambientais amplamente conhecidos. Mas o ideário do "desenvolvimento e do progresso da nação, constituem a motivação principal e a chave de legitimidade desses projetos ${ }^{15}$.

14 Ver sobre o assunto a análise de Baines (1996) sobre a Usina Hidrelétrica de Balbina e o deslocamento compulsório dos Waimiri Atroari. In: MAGALHÃES, S.; BRITO, R.; CASTRO, E. Energia na Amazônia. Belém: MPEG/UFPA/UNAMAZ, 1996.

15 O apagão é um termo que ficou conhecido para designar um período de falta grave de energia, generalizado ou localizado. No sentido negativo de que se distancia de padrões para um pais desenvolvido, condicionando a solução ao apagão no discurso de governo, às licenças de instalação de hidrelétricas que, por isso mesmo, deveriam passar por um rito de licenciamento (ambiental, sobretudo) mais flexível e célere. 


\section{CARTAS MARCADAS E MEGA BARRAGENS NO BRASIL}

A alteração territorial que presenciamos hoje, na Amazônia, resulta de importantes mudanças que ocorreram na sociedade e na economia nas últimas décadas. Dentre essas mudanças, destacam-se as novas demandas do mercado mundial e a diferenciação interna de setores econômicos que alteraram os processos de produção, os sistemas de uso da terra e a estrutura da propriedade. Seu entendimento requer que se considere a interação entre os processos locais e a dinâmica de mercados globais, fundamental para se identificar as conexões lógicas que explicam o interesse do complexo mercado transnacional e a pressão de agentes econômicos sobre os recursos naturais.

A crise econômica mundial recente, que provocou uma retração do mercado mundial e uma redução na dinâmica das trocas, mostrou, no entanto, que os produtos primários continuam a ter papel importante na economia e na balança comercial brasileira. Aliás, no Brasil nunca deixaram de ter. Tratase de produtos agrícolas, e certa indústria do agronegócio, e de bens primários intensivos de recursos naturais. Se o Brasil diversificou, ao longo do século XX, seu parque industrial e aumentou sua inserção com manufaturados na economia mundo, nas últimas décadas priorizou as políticas de incentivo à produção e à exportação de commodities e aposta ainda, de forma determinante, no crescimento do agrobusiness e do mercado exportador de alimentos. Essa é uma das crenças cintilantes das elites do agro, ainda que o mercado esboce alta vulnerabilidade. O processo de desindustrialização em curso faz parte da tendência de retomada neoextrativa, com primarização da economia.

Outro braço forte da exportação de commodities é a mineração. Observase o aumento na extração de minérios e na prospeção de ocorrências minerais, e a corrida acelerada por empresas nacionais e internacionais para chegar mais rápido aos nichos principais das ocorrências minerais. Os interesses sobre os recursos naturais de solo e subsolo, tem levado a pressões sobre novos territórios com terras agriculturáveis, florestas ricas biodiversidade e água abundante. Os espaços transfronteiriços, para além, portanto, do território brasileiro, tornaramse áreas de expansão, e de intervenção das políticas governamentais com os grandes projetos de infraestrutura - transporte e energia - e por empresas de diversos setores econômicos.

Os estudos têm mostrado ainda que a produção de energia hidrelétrica está longe de ser limpa, se considerarmos todas essas dimensões que o setor elétrico, em muitos países a América Latina, rejeita como resultantes da ação de seus empreendimentos (ROJAS, 2014). 
Ainda que se tratem de projetos de geração de energia, tornou-se essencial entender o papel que a água e os cursos de rios volumosos passaram a ter, sobretudo a partir da segunda metade do século XX, e sua relação com a coalizão de interesses privados em torno dos serviços advindos dos recursos hídricos. $\mathrm{O}$ empresariamento de Belo Monte, e de um extenso território do entorno, além dos processos de apropriação da terra que se tornaram mais agudos e céleres após a decisão política de liberar a licença ambiental, aqueceu o mercado de terras e a grilagem, com elevação do preço do solo urbano e dos aluguéis urbanos, o que pode significar um primeiro passo na direção da privatização de outros recursos e serviços relacionados à água e aos rios. Os grupos locais que formulam críticas as barragem se apoiam em argumentos onde se inclui a privatização do projeto, o barramento do rio, o que justifica, a seus olhos, as mobilizações e negociações em curso há mais de 20 anos para impedir a construção desses megaempreendimentos (SWITKES; BONILHA, 2008).

Os espaços transfronteiriços tornaram-se áreas de expansão de mercado, cujos interesses promovem alianças e disputas por empresas de diversos setores econômicos, e das políticas governamentais com os grandes projetos de infraestrutura de transporte e energia. ${ }^{16}$ Mas a fronteira se refaz na atualidade. A Amazônia tornou-se central na perspectiva do Brasil se tornar um gigante das commodities agrícolas e minerais, conforme mostram os projetos e ações governamentais, de médio e curto prazo, voltados para a construção de grandes obras de infraestrutura (transporte, energia e comunicação) ${ }^{17}$. Semelhante ao ocorrido na década de 1970, com a cessão de terras para instalação do Programa Grande Carajás, as transformações em curso mostram a rapidez do processo de apropriação de terras e de assentamento das bases de um novo projeto empresarial. Ele empurra para mais longe as fronteiras. Trata-se de um avanço

16 O extrativismo continua a se impor, ainda que estejamos no século XXI, junto com o avanço das monoculturas, do eucalipto ao pinus, dendê e aos grãos. Efetivamente o reconhecimento da expansão do neoextrativismo tem fortalecido a consciência da importância de construir argumentos que possam fazer face a uma proposta alternativa de sociedade na direção de formular estratégia pós-extrativistas, presente e que tende a crescer no pensamento político e critico na América Latina. Tem a ver com várias questões: o crescimento dos impactos sociais e ambientais provocados pelos grandes empreendimentos. $\mathrm{O}$ avanço das hidrelétricas e da mega mineração compromete territórios e modos de vida (humanos e não humanos) a biodiversidade das florestas e a água. $\mathrm{O}$ avanço dessa fronteiras se faz com velocidade nunca observada, com simultaneidade de ações e estratégias de agentes econômicos, depredação em grande escala, cujos impactos não são nem sequer reconhecimento ou mesmo imaginados (caso de Mariana), em tal ordem que nem o sistema jurídico e nem a capacidade institucional do Estado daria garantias de solução dos impactos. Ha um campo do saber a construir.

${ }_{17}$ A monocultura de eucalipto, dendê e soja, e o neoextrativismo mineral se impõem junto com o avanço da fronteira hidrelétrica. Os interesses econômicos mundiais sobre os recursos naturais de solo e subsolo tem levado, continuamente, ao aumento das pressões sobre terras, florestas e água. 
em direção às fronteiras florestais, às reservas minerais, enfim, lá onde a natureza está mais preservada (FEARNSIDE, 2015). A tensão cresce entre os povos indígenas cujas manifestações em Brasília visibilizaram uma situação dramática de ameaças, esvaziando direitos e garantias constitucionais, e os criminalizando. O tema tem sido objeto de intervenções da Associação Brasileira de Antropologia (ABA) (OLIVEIRA, 2014), na linha de interpretação de direitos, como mostram inúmeros trabalhos (OLIVEIRA, 2014; FISHER, 2014). Nesse novo contexto do século XXI, discute-se a relação entre território, territorialidade e os conflitos, identificando velhas práticas de planejamento baseadas na integração nacional, em que a logística de transporte permanece como eixo principal. E nessa direção que podemos entender os processos de mudança que ocorrem nessa porção amazônica da América Latina.

Nos últimos anos foram identificadas na região do rio Xingu jazidas de: bauxita, caulim, manganês, ouro, cassiterita, cobre, níquel, nióbio e urânio. Justamente nessa região foi definida a construção das hidrelétricas de Belo Monte, e do Complexo Teles Pires e Complexo Tapajós, todas elas pensadas para viabilizar a grande mineração, junto com os projetos para fomentar os corredores de exportação de grãos e de gado. Formam assim um complexo sistema de infraestrutura. E os interesses pelas Terras Indígenas, ricas em minérios - caso da região do Xingu que tem ocorrência de ouro, diamante, nióbio, cobre, fósforo, fosfato -, e sua deslegitimação como a afirmação de ideias como riquezas para o desenvolvimento, e muita terra para poucos índios. Esse ideário sempre esteve presente nos discursos coloniais sobre a Amazônia, reiterados pelas elites nacionais empresariais, governamentais e militares. Mas o que se observa, neste momento, é o seu fortalecimento. E considero que a Amazônia talvez passe por um momento de maior impacto social e ambiental já experimentado. Tanto pelo fluxo de interesses nacionais e internacionais, sentido no mercado de terras e na mobilidade de investimentos, a exemplo do que ocorre no oeste do Pará (Terra do Meio e Tapajós), quanto pela articulação do poder político na direção de desmontar, na prática, a legislação ambiental, e, enfim, desregulamentar dispositivos legais de maior garantia aos povos tradicionais e seus modos de ocupação da terra.

A cobiça pelas Terras Indígenas por parte das empresas de mineração não é nova. Mas a polêmica sobre a extração de minérios em terras indígenas voltou a crescer, e a tendência é a autorização do governo para mineração em TI, de forma sumária, considerando o subsolo da União. Assim, rapidamente aumentou o número de títulos minerários em TI. O relatório do Instituto Socioambiental informa que são mais de 70 processos incidentes sobre terras indígenas. Do total de 773.000 hectares delimitados como Terras Indígenas, 63\% são de interesse para extração de minério, ou seja, 496.373 hectares. 
A empresa canadense Belo Sun Mining Corp. tem dois mega projetos de mineração de ouro - Volta Grande (no Xingu) e Patrocínio (no Tapajós) - , todos eles viabilizados pela construção da hidrelétrica de Belo Monte. O Relatório de Impacto Ambiental (RIMA) do projeto Volta Grande, além de lacunas, imprecisões e falsas informações, representa uma peça colonial de dominação de um território com o aval do Governo Federal e do Governo do Pará. Inicialmente, estimaram o projeto Volta Grande em US\$ 1.076.724.000,00. As negociações com a Belo Sun Mining Corp desenvolveu-se sob sigilo criminoso, escondendo da sociedade não somente a "venda" de terras como a cessão de enormes jazidas de ouro e diamante, em troca de resultados duvidosos, embora os discursos de legitimação junto à sociedade fossem sempre os de geração de emprego, recursos para executar um plano de desenvolvimento com infra-estrutura social - escolas, hospitais etc. - para a região. Em 2017 ficou mais claro como se articulavam os interesses em torno desse mega projeto. As investigações da Ministério Público face às denúncias recebidas, e da Polícia Federal, revelou que Belo Monte foi objeto de negociadas espúrias entre empresas e políticos, no esquema de propinas e de subornos, estando envolvidos o Ministro de Minas Energia, Edson Lobão, grupo de funcionários de alto escalão da gestão pública e de inúmeros políticos.

Os desdobramentos desse movimento da economia nos territórios, esclarecidos pela pesquisa crítica e comprometida social e ambientalmente, mostram o lugar social da produção de informações e da construção coletiva de interpretações, estratégias, conceitos e novas narrativas sobre esse campo complexo que é o de estudos sobre grandes empreendimentos hidrelétricos.

\section{CONSIDERAÇÕES FINAIS}

Os estudos sobre o avanço da fronteira ocorrido nos anos 1950 a 1970, no oeste do Brasil, e na sequência, em direção à Amazônia, mostraram a relação com a violência como parte intrínseca à modernização e ao ideário performativo da dominação (MARTINS, 1980; IANNI, 1984) e sobretudo grandes obras construídas durante os regimes autoritários em um estado de exceção (AGAMBEN, 2014). Esse havia sido também o caráter do movimento de expansão da fronteira do Centro-Sul, no Brasil, impulsionado pelo aumento da demanda de produtos agrícolas seja por mercados internos, urbanos, seja para atender a pauta de exportação que exigia o aumento das áreas produtivas. A relação central sociedade x natureza estava na base desse processo. A expansão das frentes pioneiras em direção à floresta tropical aparecia, aos olhos das elites nacionais interessadas na abertura de novos territórios de recursos, como uma 
oportunidade de mercado. A dinâmica econômica refez os fluxos de migrantes e acabou envolvendo novos segmentos da sociedade nacional, na fronteira em movimento incorporada ao espaço nacional e global. Tal processo atendia aos interesses de controle das fronteiras continentais e de afirmação do compromisso com o projeto de modernização nacional.

A pesquisa e os pesquisadores, como também os movimentos sociais, étnicos e ambientalistas, têm produzido narrativas contundentes sobre a destruição dessa imensa floresta tropical e de seus rios que conformam um sistema integrado, em nome de interesses privados de mercado, como mostram os trabalhos de McCully (2004) e Rothman (2008), face a programas desenvolvimentistas de construção de grandes obras, negando o sentido dado à água para a vida e não para a morte, como assinala Carlos Vainer (2004).

Os encontros em diversas regiões do Brasil tiveram motivações distintas. Uma densa colaboração com atores locais, identificando situações críticas, buscando categorias de análise e conceitos capazes de explicitar as narrativas do setor elétrico sobre a obra; dos agentes públicos e suas agências; das interferências externas de agentes do mercado para aprovação pelos órgãos competentes em casa caso; análise dos Estudos de Impacto Ambiental, os direitos e permissões, os riscos e as incertezas, ao longo dos processos de licenciamento, momento fundamental onde o contraditório e os interesses do setor elétrico se explicitam. $\mathrm{E}$, por isso, as escolhas de problemas para pesquisa na área de humanidades acompanha essas questões que emergem no correr do processo de instalação de uma mega hidrelétrica, seja associados ao planejamento, à implantação e à operação das usinas, e demais agentes envolvidos, em especial as populações atingidas e os grupos ambientalistas.

Destacamos algumas sugestões de temas que nos parecem relevantes para a prática da pesquisa nesse campo: 1. debate sobre novas epistemologias, descolonização de saberes, conceitos, narrativas; 2. pesquisa-ação e conhecimento sobre territórios e direitos; 3. redes de construção de saberes latino-americano para desenvolver estudos comparados; 4. dispositivos legais para fortalecimento dos direitos sobre territórios comuns e atribuição de poder de impedimento aos coletivos; 5 . produção e difusão de análises para subsidiar agências governamentais e organizações da sociedade civil no debate público e na implementação de políticas relacionadas ao planejamento, implantação e operação de usinas hidrelétricas; 6. construção de novas narrativas sobre saberes, direitos, ecologia política e controle social.

Finalmente, cabe registrar que os movimentos sociais vivem processos intensos relacionados à defesa de direitos sociais, étnicos e ambientais. Sua 
prática social tornou-se uma fonte inesgotável de criação e construção de um pensamento político contemporâneo. Eles têm se articulado em redes nacionais e mundiais contra as barragens de rios, e continuam construindo argumentos que contrariam aqueles que defendem a construção de grandes barragens como solução energética. Nas interpretações sustentadas ao longo dessas décadas e divulgados por uma série de materiais que foram por nós consultados e analisados, eles têm defendido bandeiras relacionadas aos direitos territoriais, à integridade de seus territórios e à vida, numa dimensão integeracional e supra nacional. Contestam a natureza dos investimentos, os financiamentos e financiadores, os interesses em jogo, os principais beneficiários, e sobretudo, como essas dinâmicas produzem processos de desterritorilização e de violência contra populações rurais, indígenas e quilombolas; deslocamentos forçados pelas inundações ou mudança na qualidade dos recursos florestais e aquáticos, impasses nas formas anteriores de mobilidade pelos rios, e, inviabilização de processos de trabalho, produção de gases de efeito estufa e outros elementos químicos nocivos que se desdobram e se derramam em processos múltiplos.

\section{REFERÊNCIAS}

ACSELRAD, H. Planejamento autoritário e desordem socioambiental na Amazônia: crônica do deslocamento de populações em Tucuruí. RAP, Rio de Janeiro,v. 25, n. 4, p. 53-68, out-dez, 1991.

AGAMBEN, G. Comment l'obsession sécuritaire fait muter la démocratie. Le Monde diplomatique, Paris/França, p. 22-23, janvier, 2014. Disponível em: <http:/ /www.monde-diplomatique.fr/2014/01/AGAMBEN/49997>. Acesso em: 13 jan. 2017.

ALBERT, B - O ouro canibal e a queda do céu: uma crítica xamânica da economia política da natureza. Série Antropologia, no. 174, UnB, Brasília, 1995

ALMEIDA, A. W. B. (Org.). Conflitos sociais no complexo do Madeira. Manaus: Ed. UEA, 2009.

ANTONAZ, D. Especialistas e militantes: um estudo a respeito da gênese do pensamento energético no atual governo (2002-2005). In: SEVÁ, O. (Org.). Tenotã-Mõ. Alertas sobre as conseqüências dos projetos hidrelétricos no rio Xingu. Brasília: IRN, 2005. p. 150-172.

BAINES, A. Usina Hidrelétrica de Balbina e o deslocamento compulsório dos Waimiri Atroari. In: MAGALHÃES, S., BRITO, R.; CASTRO, E. (Orgs.). Energia na Amazônia. Belém: MPEG; UFPA; UNAMAZ, 1996. p. 381-398. 
BELTRÃO, J. F; OLIVEIRA, A. de C.; PONTES JUNIOR, F. Significados do direito à consulta: povos indígenas versus UHE Belo Monte. In: OLIVEIRA, J. P; COHN, C. (Org.). Belo Monte e a questão indígena. Brasília: ABA, 2014. p. 70-101.

BERMANN, C. A resistência às obras hidrelétricas na Amazônia e a fragilização do Ministério Público Federal. Revista Novos Cadernos NAEA, Belém, v. 16, n. 2, p. 97-120, jul./dez. 2013.

CAPES - Coordenação de Aperfeiçoamento de Pessoal de Nível Superior. Catálogo de teses e dissertações. 2018. Disponível em: <https:// catalogodeteses.capes.gov.br/catalogo-teses/\#!/>. Acesso em: 14 fev. 2019.

CARNEIRO, D. S. Do latifúndio agropecuário à empresa latifundiária carvoeira. In: COELHO, M. C. N.; COTA, R. G. (Orgs.). 10 anos da Estrada de Ferro Carajás. Belém: UFPA/NAEA, 1997. p. 69-87.

CARNEIRO DA CUNHA, M. \& BARBOSA, S. (Orgs.). Direitos dos povos indígenas em disputa. São Paulo: Editora da Unesp, 2018

CARVALHO, M. R. A Usina Hidreletrica de Itaparica (BA) e deslocamentos de indios e camponeses. In: MAGALHÃES, S.; BRITO, R.; CASTRO, E. (Orgs.). Energia na Amazônia. Belém: MPEG; UFPA; UNAMAZ, 1996. v. 2. p. 605-630.

CASTRO, E. Campo do desenvolvimento, racionalidade, ciência e poder. In: FERNANDES, A. C.; LACERDA, N.; PONTUAL, V.(Orgs.). Desenvolvimento, planejamento e governança: o debate contemporâneo. Rio de Janeiro: Letra Capital, 2015. p. 225-246.

- Expansão da fronteira, megaprojetos de infraestrutura e integração sul-americana. Salvador. Cadernos do CRH (Dossiê Amazônia, Fronteiras e Poder), Salvador, v. 25, n. 46, p. 45-62, 2012.

- Políticas de Estado e atores sociais na Amazônia contemporânea. In: BOLLE, W.; CASTRO, E.; VEJMELKA, M. (Orgs.). Amazônia, região universal, teatro do mundo. São Paulo: Ed. Globo, 2010. v. 1, p. 105-122.

- Resistência dos atingidos pela barragem de Tucuruí e construção de identidade. In: CASTRO, E.; HÉBETTTE, J. (Org.). Na trilha dos grandes projetos: modernização e conflito na Amazônia. Cadernos do NAEA, Belém: UFPA; NAEA, n. 10, p. 9-28, 1989.

CASTRO, E.; ALONSO, S.; NASCIMENTO, S.; CORREA, S. Hidrelétricas na Amazônia e grandes dilemas postos à sociedade no século XXI. Papers do NAEA, Belém, n. 343, p. 4-26, 2014. 
DAOU, A. M. L. Os "desobrigados" da barragem: longe e perto do lago. Uma reflexão sobre o desovamento compulsório em Sobradinho. In: MAGALHÃES, S.; BRITO, R.; CASTRO, E. (Orgs.). Energia na Amazônia. Belém: MPEG; UFPA; UNAMAZ, 1996. v. 2. p. 477-490.

FEARNSIDE, P. Gases de efeito estufa no EIA-RIMA da hidrelétrica de Belo Monte. Novos Cadernos NAEA, Belém, v. 14, n. 1, p. 5-19, jan./jun. 2011.

Hidrelétricas na Amazônia: impactos ambientais e sociais na tomada de decisões sobre grandes obras. Manaus: Editora do INPA, 2015.

FERRAZ, I. Resposta a Tucuruí: o caso dos Parkatêjê. In: MAGALHÃES, S.; BRITO, R.; CASTRO, E. (Org.). Energia na Amazônia. Belém: MPEG; UFPA; UNAMAZ, 1996. v. 2. p. 537-544.

FERRAZ, I.; VIVEIROS DE CASTRO, E. Projeto Carajás e os povos indígenas: expectativas e realidade. Pará Desenvolvimento, Belém, IDESP, n. 20/21, p. 30-33, 1986/1987.

FISHER, W. O contexto institucional da resistência indígena a megaprojetos amazônicos. In: OLIVEIRA, J. P; COHN, C. (Orgs.). Belo Monte e a questão indígena. Brasília: ABA, 2014. p. 133-143.

GERMANI, G. I. Expropriados terra e água. 2. ed. O conflito de Itaipu. Salvador: EDUBA; ULBRA, 2003.

GUDYNAS, E. Extractivismos: ecología y economía política de un modo de entender el desarrollo y la naturaleza. 1. ed. Cochabamba: CEDIB, 2015.

HEBETTE, J. Cruzando fronteiras. 30 anos de estudos do campesinato na Amazônia. Belém: EDUFPA, 2004. v. 1, 2 e 3.

IANNI, O. Origens agrárias do Estado Brasileiro. São Paulo: Brasiliense,1984.

ISA - Instituto Socioambiental. Especial Belo Monte. Disponível em: http:// www.socioambiental.org/esp/bm/index.asp. Acesso em 13 jun. 2010.

LEITE LOPES, J. S. Considerações sobre formas de imobilização da força de trabalho nas fábricas com vila operária tradicionais e nos grandes projetos.In: MAGALHÃES, S., BRITO, R.; CASTRO, E. (Orgs.). Energia na Amazônia. Belém: MPEG; UFPA; UNAMAZ, 1996. v. 1. p. 407-420.

LEITE LOPES, J. S; SIGAUD L. Efeitos sociais de grandes projetos hidrelétricos: as barragens de Sobradinho e Machadinho. Rio de Janeiro: Museu Nacional, 1986. 
MAGALHÃES, A. C. Índios e Barragens: a complexidade étnica e territorial na Região do Médio Xingu. In: SEVA, O. (Org). Tenotã-Mõ: Alertas sobre as consequências dos projetos hidrelétricos no rio Xingu. São Paulo: International Rivers Network, 2005. p. 255-266.

MAGALHÃES, S. B.; BRITO, R. C.; CASTRO E. (Org.). Energia na Amazônia. Belém: MPEG; UFPA; UNAMAZ, 1996.

MARTINS, J. de S. Expropriação e violência. São Paulo: Hucitec, 1980.

MCCULLY, P. Rios silenciados. Ecología y política de las grandes represas. Buenos Aires, Argentina: Proteger Ediciones, 2004.

MME - Renováveis devem manter participação de 43\% na matriz energética de 2017. MME, Brasilia, 2017. http://www.mme.gov.br/web/guest/pagina-inicial/ outras-noticas/-/asset_publisher/32hLrOzMKwWb/.Acesso em 17 julho 2018

MME - Memória da Eletricidade - Eletrobrás, 2012.

MURPHY, K. Macroproject Development in the Third World. Boulder: Westview Press, 1983.

NASCIMENTO, S. M. Violência e estado de exceção na construção da hidrelétrica de Belo Monte. 2016. 250f. Tese (Doutorado em Desenvolvimento Sustentável do Trópico Úmido) - Núcleo de Altos Estudos Amazônicos, Universidade Federal do Pará, Belém, 2016.

NOVOA GARZON, L. F. BNDES: processos decisórios e articulação Estadocapital de 2002 a 2013. 2015. Tese (Doutorado em Planejamento Urbano e Regional) - IPPUR, Universidade Federal do Rio de Janeiro, Rio de Janeiro, 2015.

OLIVEIRA, J. P. Introdução: a ABA e a questão de Belo Monte. In: OLIVEIRA, J. P., COHN, C. (Org.). Belo Monte e a questão indígena. Brasília: ABA, 2014. p. 12-26.

PARENTE, T. G.; MIRANDA, C. M. Impactos socioculturais e gênero nos reassentamentos da Usina Luis Eduardo Magalhães/TO. Varia história, Belo Horizonte, v. 30, n. 53, p. 557-570, maio/ago. 2014.

REIS, M. J. Espaços, vivencias e identidades: os camponeses do Alto Uruguai e a hidreletrica de Itá. In: MAGALHÃES, S., BRITO, R.; CASTRO, E. (Org.). Energia na Amazônia. Belém: MPEG; UFPA; UNAMAZ, 1996. v. 2. p. 591-604.

RIBEIRO, G. L. Cuanto Más Grande Mejor? Proyectos de Gran Escala, una Forma de Producción vinculada a la expansión de Sistemas Económicos. Desarrollo Económico, Buenos Aires, Argentina, v. 27, n. 105, p. 3-27, abr./jun. 1987. 
Empresas transnacionais: um grande projeto por dentro. São Paulo: Marco Zero, 1991.

RODRIGUES, R. A.; FEARNSIDE, P. M. Índios Waimiri-Atroari impactados por tutela privada na Amazônia Central. Novos Cadernos NAEA, Belém, v. 17, n. 1, p. 47-73, jan./dez. 2014.

ROJAS, B. (Des)cumprimento das condicionantes socioambientais de Belo Monte. In: OliveIRA, J. P.; COHN, C. (Org.). Belo Monte e a questão indígena. Brasília: ABA, 2014. p. 102-121.

ROTHMAN, F. D. (Ed.). Vidas alagadas. Conflitos socioambientais, licenciamento e barragens. Viçosa, MG: Ed. UFV, 2008.

SCOTT, P.; FERRAZ DE SA, M. A. Barragem de Itaparica: indagações sobre a reconstrução da base familiar da produção agrícola. In: CASTRO, E.; MOURA, E.; MAIA, M. L. (Org.). Industrialização e grandes projetos. Desorganização e reorganização o espaço. Belém: EDUFPA, 1995. p. 285-300.

SEVA, O. Povos indigenas, as cidades, e os beiradeiros do rio Xingu que a empresa de eletricidade insiste em barrar. In: SEVA, O. (Org.). TenotãMõ. Alertas sobre as conseqüências dos projetos hidrelétricos no rio Xingu. Brasilia: IRN, 2005a. p. 29-54.

Conhecimento critico das mega hidrelétricas: para avaliar de outro modo altercações naturais, transformações sociais e a destruição dos monumentos fluviais. In: SEVA, O. (Org.). Tenotã-Mõ. Alertas sobre as conseqüências dos projetos hidrelétricos no rio Xingu. Brasilia: IRN, 2005b. p. 281-295.

SIGAUD, L. Crença, descrença e interesses: por uma sociologia das condutas face ao deslocamento compulsório. In: MAGALHÃES, S., BRITO, R.; CASTRO, E. (Org.). Energia na Amazônia. Belém: MPEG; UFPA; UNAMAZ, 1996. v. 551. p. 551-570.

SWITKES, G.; BONILHA, P. Águas turvas: alertas sobre as consequências de barrar o maior afluente do Amazonas. São Paulo: International Rivers Network Oakland, 25 jun. 2008.

VAINER C. Águas para a vida e não para a morte. In: ACSERALD, H; HERCULANO, S.; PÁDUA, J. A. (Org.). Justiça ambiental e cidadania. Rio de Janeiro: Relume/Dumará, 2004.

Conceito de "atingido": Uma revisão do debate. In: ROTHMAN, F. D. (Org.). Vidas alagadas. Viçosa-MG: Ed. UFV, 2008. p. 39-63. 
